\title{
Требования, предъявляемые к современным матричным фотоприёмникам наземных оптико-электронных систем
}

\author{
В.Д. Шаргородский ${ }^{1)}$, А.Б. Александров ${ }^{1)}$, А.А. Бабаев ${ }^{2)}$ \\ ${ }^{l}$ Акционерное общество «Научно-производственная корпорациия «Системы прецизионного \\ приборостроения», Москва, 111024, Авиамоторная, 53 \\ эл.nочта: aleksandrov@npk-spp.ru \\ ${ }^{2}$ Филиал акционерного общества «Научно-производственная корпорация «Системы прецизионного \\ приборостроения», Великий Новгород, 173003, наб. Реки Гзень, д.9
}

эл.nочта: $\underline{\text { babaevaa@npkspp.ru }}$

DOI 10.34077/RCSP2019-59

Исходя из решаемых наземными оптико-электронными системами (ОЭС) задач по наблюдению околоземного пространства, в докладе сформулированы требования, предъявляемые к используемым матричным фотоприёмникам. Рассмотрены потребности для решения текущих и перспективных задач фотометрирования, обнаружения космического мусора, измерения сигнальных и траекторных характеристик и др.

Современные фотоприёмники видимого диапазона хорошо отработаны технологически и основное направление их развития связано с повышением производительности оптико-электронных систем. Так в задаче обнаружения космического мусора, требуется использование безкорпусных фотоприёмников мозаичных матриц видимого диапазона для формирования фоточувствительных поверхностей любых размеров. Основные требования к таким приборам: размер фоточувствительной поверхности от 50х50 мм, размер пикселя не менее 10 мкм, шум считывания не более 3 ё, максимум квантовой эффективности не менее $95 \%$ на длине волны 560 нм, темновой ток не более $0,01 \mathrm{e} / \mathrm{c}$ в отдельном пикселе, динамический диапазон не менее 75дб. Плоскостность фоточувствительной поверхности должна лежать в пределах 5 мкм. Кадровая частота должная быть не менее 10 Гц и обязательным требованием является наличие электронного затвора.

В задаче фотометрирования «всего неба» требуются отечественные фотоприёмники форматом не менее двадцати мегапикселей, глобальным электронным затвором, размером пикселя не менее 6 мкм, шумом считывания не более $8 \overline{\mathrm{e}}$, максимумом квантовой эффективностью не менее $70 \%$ и динамическим диапазоном не менее 66дб. Кадровая частота должная быть не менее 30 Гц.

Для узкопольных наземных ОЭС различного назначения требуются отечественные фотоприёмники видимого диапазона размером фоточувствительной поверхности от 12х12 мм до $25 \mathrm{x} 25$ мм с размером пикселя 6-10 мкм, шумом считывания не более 1,6 $\overline{\mathrm{e}}$, максимумом квантовой эффективности не менее 95\% при длине волны 560 нм, темновым шумом не более 0,2 ё/с и динамическим диапазоном не менее 90 дб. Кадровая частота должна быть не менее 50 Гц, обязательно наличие электронных затворов типа Global Shutter и Rolling Shutter.

Фотоприёмники ближнего ИК диапазона зачастую используются в задачах дневного обнаружения. При решении таких задач требуются фотоприёмники форматом не менее 640x512 пикселей с размером не менее 25 мкм, зарядовой ёмкостью не менее $8 \cdot 10^{6} \overline{\mathrm{e}}$, шумом считывания не более $500 \overline{\mathrm{e}}$, квантовой эффективностью не менее $70 \%$, динамическим диапазоном не менее 80 дб, количеством дефектных элементов не более $0,2 \%$. Кадровая частота - не менее 50 Гц.

Для проведения сигнальных и траекторных измерений в среднем и дальнем ИК диапазоне современными отечественными наземными ОЭС требуются фотоприёмники форматом 640х512 и 1024x1024, размером пикселя не менее 24 мкм. Средняя величина разности температуры эквивалентная шуму для таких фотоприёмников должна составлять не более 12 мК, зарядовая ёмкость $18 \cdot 10^{6} \overline{\mathrm{e}}$, динамический диапазон не менее 74дб, количество дефектных элементов не более $0,2 \%$. Должно быть реализовано два режима считывания - IWR и ITR. Кадровая частота должная быть не менее 100 Гц для режима IWR и 50 Гц для режима ITR.

Помимо оптико-физических характеристик для фотоприёмников среднего и дальнего ИК диапазона важны их потребительские свойства. Типовые требования: гарантия на фотоприёмник с холодильником не менее 10 лет, средняя наработка на отказ холодильной машины не менее 10000 часов, рабочая температура холодильной машины от минус 50 до 75 градусов. 